\title{
TANTANGAN PERAN BIROKRASI SENTRALISTIK, INTEGRASI POLITIK PEMERINTAHAN DAERAH, PREDIKTOR SISTEM KOMUNIKASI NASIONAL BARU
}

\author{
Alex Rumondor \\ Universitas Kristen Indonesia \\ J1. Mayjen Soetoyo, Jakarta
}

\begin{abstract}
Indonesia experiences changing from centralized governmental system to be local based government through autonomy to manage each region. That changing will related to new national communication system, that are communication condition within government (suprastructure of communication) and communication within society (infrastructure of communication). Communication is understood in its state context with its value system Pancasila and Constitution 1945, culture and the existing institutions. Within this framework bureaucracy communication which is centralistic will face challenge, that is how suprastructur and infrastructure communication can be maintained and operate in the balance way to achieve nation-state integration.
\end{abstract}

Keywords: Centralistic Bureaucracy, Regional Government, New National Communication System

Abstrak: Indonesia mengalami perubahan dari sistem pemerintahan sentralisik menjadi pemerintah berbasis lokal melalui otonomi untuk mengatur masing-masing daerah. Perubahan tersebut akan berkaitan dengan sistem komunikasi nasional baru, yaitu suasana komunikasi dalam pemerintahan (suprastruktur komunikasi) dan komunikasi dalam masyarakat (infrastruktur komunikasi). Komunikasi dipahami dalam konteks kenegaraan dengan sistem nilainya Pancasila dan UUD 1945, budaya serta berbagai lembaga yang ada. Dalam kerangka ini komunikasi birokrasi yang masih bersifat sentralistik akan menghadapi tantangan, yaitu bagaimana suprastruktur dan infrastruktur komunikasi dapat dipertahankan dan berjalan seimbang untuk mencapai integrasi negara bangsa.

Kata Kunci: Birokrasi Sentralistik, Pemerintah Daerah, Sistem Komunikasi Nasional Baru.

\section{Pendahuluan}

Sistem Negara Kesatuan Republik Indonesia (NKRI) dewasa ini berada di tengah-tengah reformasi demokrasi era globalisasi. Pemerintahan Daerah mengatur dan mengurus sendiri urusan pemerintahan menurut asas otonomi dan tugas perbantuan diarahkan untuk mempercepat terwujudnya kesejahteraan masyarakat melalui peningkatan pelayanan, pemberdayaan dan peran serta masyarakat, serta peningkatan daya saing daerah; dengan memperhatikan prinsip demokrasi, pemerataan, keadilan, keistimewaan dan kekhususan daerah-daerah dalam sistem 
NKRI (Pertimbangan Undang-Undang Pemda No.32 Tahun 2004), tatanan normatif menurut UUD 1945 Amandemen ke-2; menurut asas desentralisasi oleh penyelenggara pemerintah daerah dan DPRD. Ini berarti peran sentralisasi yang selama pemerintahan Orde Baru, dianggap sebagai syarat mutlak bagi kelangsungan hidup kesatuan dan persatuan Negara RI sudah bergeser ke peran desentralisasi. Demikian juga dengan sistem komunikasi Indonesia bergeser ke sistem komunikasi nasional "baru”.

Sistem komunikasi Indonesia diwujudkan oleh dua suasana kehidupan komunikasi sebagai totalitas sistem, yaitu suasana kehidupan komunikasi dalam pemerintahan yang disebut suprastruktur komunikasi dan suasana kehidupan komunikasi dalam masyarakat yang disebut infrastuktur komunikasi. Kedua suasana ini dalam kerangka sistem disebut sub-sistem suprastruktur dan sub-sistem insfrastruktur. Dalam bekerjanya proses sistem, kedua suasana ini saling tergantung dan terjadi pengaruh timbal balik.

Di dalam sistem pemerintahan dan sistem politik, terwujud dua suasana kehidupan politik masyarakat (Almond G. dan Coleman, 1985). Kedua suasana tersebut adalah The Govermental Political Sphere, dimaksudkan sebagai "suasana kehidupan politik pemerintahan atau disebut pula suprastruktur politik, dan The Social Political Sphere, dimaksudkan sebagai suasana kehidupan masyarakat atau disebut juga infrastruktur politik. Maka sistem komunikasi pun terdiri dari dua suasana kehidupan yaitu: suprastruktur komunikasi dan infrastruktur komunikasi. Dalam kerangka totalitas sistem komunikasi nasional Indonesia maka supratruktur komunikasi terdiri dari lembaga-lembaga otoritas sebagai pengelola, pengendali dan mengoperasikan sumber-sumber komunikasi sesuai lingkup, wewenang, tugas, dan tanggungjawab masingmasing lembaga (mengikuti Struktur Ketatanegaraan Republik Indonesia setelah perubahan Undang-Undang Dasar tahun 1945. Sedangkan di daerah merupakan otonomi para Bupati, Kepala Daerah, dan Walikota didampingi oleh Dewan-Dewan Perwakilan Rakyat Daerah-DPD, menurut UUD 1945, pasal 18 ayat 2.

Untuk memahami bagaimana terapan ilmu komunikasi setelah memasuki wilayah sistem atau dunia empiris sebagai Das Sein dalam hal ini adalah wilayah sistem nilai Indonesia, dengan sistem nilai filsafat Pancasila, maka bagan ini mencoba menunjukkannya: 


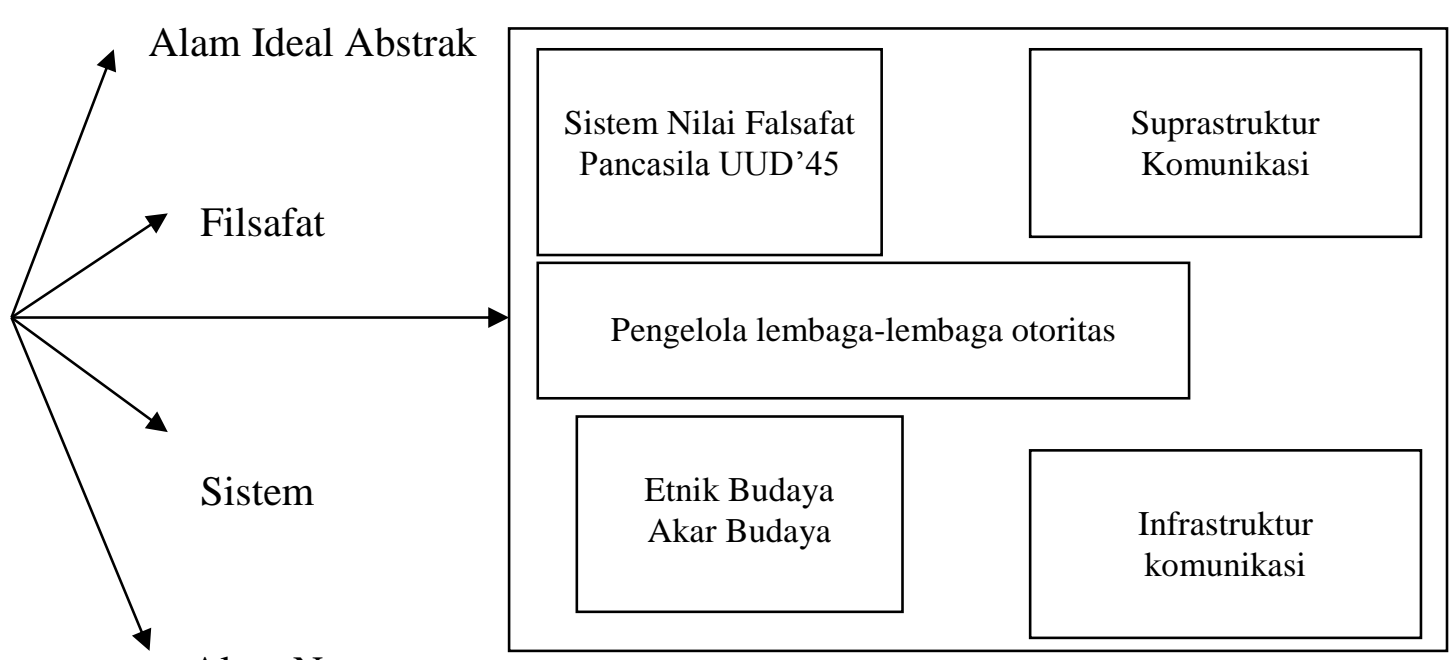

Alam Nyata

Perubahan tatanan pemerintahan ini terlebih lagi bersifat asasi, tidak mungkin dibayangkan tanpa pergertian tentang perubahan komunikasi (Prof. Andre Harjana, 2001). Sebab tanpa komunikasi, proses pemerintahan yang demokratis tidak akan berlangsung.

Karakteristik sistem komunikasi Indonesia atau sistem komunikasi nasional baru dalam otonomi daerah bersumber dari landasan yuridis formal (UU No.32 Tahun. 2004 Bab III Pasal 10 Ayat 3 dan Pasal 5 mengenai kewenangan pemerintah daerah).

\section{Perubahan Karakteristik Sistem Komunikasi Indonesia Di Era Otonomi Daerah}

Menurut asas desentralisasi (UU Pemda No. 32 Tahun 2004 Pasal 1 (7), pemerintah menyerahkan wewenang kepada daerah otonom untuk mengatur dan mengurus urusan pemerintahan dalam sistem Negara Kesatuan Republik Indonesia (NKRI). Hal ini berarti daerah memiliki kewenangan mengelola sumber-sumber komunikasi daerah yaitu mulai dari kebijaksanaan membentuk sumber, mengelola samapai mengoperasikannya berada pada daerah sebagaimana dalam tatanan normatif daerah otonom berikut.

Munculnya daerah otonom sebagai ketentuan yang ditetapkan Pasal 18 UUD 1945 Amandemen II Ayat (1) NKRI dibagi atas daerah-daerah provinsi, dan daerah-daerah provinsi itu dibagi atas kabupaten dan kota, yang tiap-tiap provinsi, kabupaten dan kota mempunyai pemerintah daerah yang diatur dengan undang-undang. Menurut UUD 1945 Pasal 18 Ayat (2) Pemerintah daerah provinsi, daerah kabupaten, dan kota mengatur dan mengurus sendiri urusan pemerintahan menurut asas otonomi dan tugas pembantuan; dan (6) Pemerintah daerah berhak 
menetapkan peraturan daerah dan peraturan-peraturan lain untuk melaksanakan otonomi dan tugas pembantuan.

Pelaksanaan pasal 18 UUD 1945 adalah melalui UU Pemerintahan Daerah No.32 Tahun 2004 Pasal 1 (5) Otonomi Daerah adalah hak, wewenang, dan kewajiban daerah otonom untuk mengatur dan mengurus sendiri urusan pemerintahan dan kepentingan masyarakat sestempat sesuai dengan peraturan perundang-undangan. Daerah otonom, selanjutnya disebut daerah, adalah kesatuan masyarakat hukum yang mempunyai batas-batas wilayah yang berwenang mengatur dan mengurus urusan pemerintah dan kepentingan masyarakat setempat menurut prakarsa sendiri berdasarkan aspirasi masyarakat dalam sistem NKRI (UU Pemda No.32 Tahun 2004 Pasal 1 (6). Dan NKRI dibagi atas daerah-daerah provinsi dan daerah provinsi itu dibagi atas kabupaten dan kota yang masing-masing mempunyai pemerintahan daerah (UU Pemda No.32 Tahun 2004 Pasal 2 (1). Tugas pembantuan adalah penugasan dari pemerintah kepada dan/atau desa dari pemerintah provinsi kepada kabupaten/kota/ dan/atau desa setara dari pemerintah kabupaten/kota kepada desa untuk melaksanakan tugas tertentu (UU Pemda No.32 Tahun 2004 Pasal 1 (9). Urusan pemerintah yang dilimpahkan kepada Gubernur disertai dengan pendanaan sesuai dengan urusan yang didekonsentrasikan (UU Pemda No.32 Tahun 2004 Pasal $12(2)$.

Ketentuan tersebut merupakan tatanan normatif menurut UUD 1945 Amandemen ke-2 yang memberikan keleluasan kepada daerah untuk menyelenggarakan otonomi daerah. Disamping melaksanakan otonomi, pemerintah daerah juga berhak melaksanakan tugas pembantuan, yaitu penugasan dari pemerintah kepada daerah dan desa tertentu yang disertai pembiayaan sarana dan prasarana serta sumber daya manusia dengan kewajiban melaporkan pelaksanaannya dan mempertanggungjawabkannya sesuai urusan yang didekonsentrasikan. Dekonsentrasi adalah pelimpahan wewenang pemerintah oleh pemerintah kepada Gubernur sebagai wakil pemerintah dan/atau kepada instansi vertikal di wilayah tertentu (UU Pemda No.32 Tahun 2004 Pasal 1 (8). Tugas Gubernur sebagai wakil pemerintah bertanggung jawab kepada Presiden, dan memiliki tugas dan wewenang (a) pembinaan dan pengawasan penyelenggaraan pemerintah daerah kabupaten/kota; (b) koordinasi penyelenggaraan urusan pemerintah di daerah provinsi dan kabupaten/kota; (c) koordinasi pembinaan dan pengawasan penyelenggaraan tugas pembantuan di daerah provinsi dan kabupaten/kota (UU Pemda No.32 Tahun 2004 Pasal 37-38).

Pelaksanaan otonomi daerah merupakan penyelenggaraan pemerintah daerah otonom oleh pemerintah daerah dan DPRD (UU Pemda No.32 Tahun 2004 Pasal 3) menurut asas 
desentralisasi. Hal ini berarti, prinsip sentralisasi yang selama pemerintahan Orde Baru dianggap sebagai syarat mutlak bagi kelangsungan hidup kesatuan dan persatuan negara Republik Indonesia diganti dengan desentralisasi.

Sesuai dengan nilai-nilai demokrasi, pemikiran baru dapat muncul dari sikap keterbukaan, dan kesungguhan para pejabat publik mendengarkan aspirasi masyarakat. Perubahan tatanan pemerintahan, apalagi yang bersifat asasi, tak mungkin dibayangkan tanpa pengertian tentang perubahan komunikasi. Sebab tanpa komunikasi proses pemerintahan yang demokratis tidak akan berlangsung. Karakteristik sistem komunikasi Indonesia dalam otonomi daerah bersumber dari landasan yuridis formal UU No.32 Tahun 2004 tentang Pemerintahan Daerah Bab III/Pembagian Urusan Pemerintahan /Pasal 10 ayat (3): Kewenangan daerah mencakup kewenangan dalam seluruh bidang pemerintahan, kecuali kewenangan dalam bidang politik luar negeri, pertahanan, keamanan, yustisi (peradilan), moneter, fiskal nasional, dan agama. Kemudian pasal (5) menyatakan dalam urusan pemerintahan yang menjadi kewenangan pemerintahan di luar urusan pemerintahan sebagaimana dimaksud pada ayat (3), pemerintah dapat: (a) menyelenggarakan sendiri sebagian urusan pemerintahan; (b) melimpahkan sebagian urusan pemerintahan kepada Gubernur selaku wakil pemerintah; atau (c) menugaskan sebagian urusan kepada pemerintahan daerah dan/atau pemerintahan desa berdasarkan asas tugas perbantuan.

Kewenangan propinsi sebagai wilayah administrasi mencakup urusan wajib dalam skala propinsi (UU No 32 Tahun 2004 Pasal 13) meliputi antara lain: perencanaan dan pengendalian pembangunan; perencanaan, pemanfaatan, dan pengawasan tata ruang; penyelenggaraan ketertiban umum dan ketentraman masyarakat; bidang kesehatan, pendidikan, masalah sosial lintas kabupaten/kota; ketenagakerjaan, penanaman modal dan pelayanan administrasi umum pemerintahan. Pasal 14 (1) tentang urusan wajib yang menjadi kewenangan pemerintahan daerah untuk kabupaten/kota merupakan urusan yang berskala kabupaten/kota meliputi antara lain: perencanaan dan pengendalian pembangunan; perencanaan, pemanfaatan, dan pengawasan tata ruang; penyelenggaraan ketertiban umum dan ketentraman masyarakat; bidang kesehatan, pendidikan, masalah sosial lintas kabupaten/ kota; ketenagakerjaan, penanaman modal dan pelayanan administrasi umum pemerintahan. Jika dilihat dari rumusan UU yang mengatur kewenangan pemerintah daerah, maka menjadi penting untuk dicermati, apakah berpengaruh terhadap perubahan sistem komunikasi pemerintahan di daerah yang sebelumnya sentralistik. (Andre Haryana, 2001) 


\section{Birokrasi Sentralistik Menggusur Komunikasi Sosial dan Efektivitas Administrasi}

Birokrasi sentralistik adalah ciri khas negara-negara berkembang baik yang beraliran sosialistis maupun "Otoriter", termasuk yang menyatakan diri sebagai negara demokrasi kerakyatan. Sedangkan birokrasi sentralistik di negara berkembang termasuk Indonesia tidak hanya mengandalkan kekuatannya pada sistem komunikasi administratif yang fungsional struktural dan pengendalian unilateral-vertikal sebagai instruksi dari atas ke bawah, tetapi juga dengan mobilisasi dukungan partai pemerintah yang pada dasarnya mengikuti struktur kekuasaan. Kita tentu masih ingat peranan dan fungsi Golongan Karya (GOLKAR) di masa Orde Baru. Birokrasi menjadi mesin legitimasi setiap keputusan dan kebijakan yang dibuat oleh pemerintah. Golkar menempatkan mesin politik pada pusat penyelenggara kekuasaan birokrasi sentralistik. Dalam konteks sosial politik sistem komunikasi nasional berlangsung secara formal mengikuti struktur birokrasi yang sentralistis berbentuk komunikasi administratif, yakni komunikasi formal demi kepentingan birokrasi pemerintah pusat. Di sisi lain komunikasi sosial yang mengandung nilai relasional dan interaksional berorientasi kemanusiaan dan kebangsaan, tergusur oleh komunikasi formal yang legalistis dan birokratis impersonal.

Dalam konteks sosial politik komunikasi sosial ini dikenal dengan budaya politik tradisional yang dalam masalah integrasi politik NKRI sering menimbulkan konflik dengan "Budaya Politik Pemerintah" yang birokratis sentralistik. Budaya politik terutama sistem kepercayaan pandangan dunia, mitos dan ideologi yang menjadi basis interaksi sosial politik serta kepemimpinan.

Dalam konteks komunikasi antar budaya (KAB) atau Intercultural Communication; komunikasi di antara individu yang berbeda latar belakang nilai-nilai kepercayaan, pendidikan dari kelompok budaya tertentu yang juga rawan konflik dalam sistem komunikasi nasional antara lain konflik antara birokrasi pemerintah pusat maupun daerah dalam memelihara dan mempertahankan kepemimpinan sistem NKRI.

KAB pada dasarnya merupakan salah satu kajian dalam ilmu komunikasi sistem komunikasi nasional yang dilakukan dengan cara memahami unsur-unsur kebudayaan para pelaku komunikasi (Rumondor, 1995). Dalam arti memahami unsur-unsur budaya politik pemerintah kepada pemerintah daerah dengan budaya politik tradisionalnya seperti paparan sebelumnya.

Dalam konteks sosial politik pula otonomi daerah sebagai gabungan dari desentralisasi dan debirokratisasi adalah pemberian sebagian dari kekuasaan negara kepada pemerintahan 
daerah untuk mendekatkan kekuasaan negara kepada rakyat; semakin dekat kekuasaan negara kepada rakyat, semakin mudah pula rakyat ikut mengendalikan negara melalui peningkatan partisipasi politik masyarakat dalam proses penyelenggaraan negara mulai dari pemilihan penyelenggara negara sampai dengan proses penetapan kebijakan publik, pelaksanaan dan evaluasinya. (Merphin Panjaitan, 2011). Hal ini lebih mudah bagi rakyat dari pada harus datang ke Jakarta untuk mempengaruhi pemerintah "pusat" seperti di era orde baru. NKRI geopolitik Republik Indonesia dengan luas wilayah sekitar $5.000 .000 \mathrm{Km} 2$ dan penduduknya sekitar 240.000.000 jiwa, akan sulit dikendalikan rakyat kalau segala sesuatu tentang negara harus diputuskan di Jakarta.

Pelaksanaan otonomi daerah adalah sebuah perbaikan birokrasi dan demokratisasi kehidupan sosial masyarakat dalam rangka peningkatan kesejahteraan masyarakat. Dinamika komunikasi antar segenap jaringan yang meningkatkan keterlibatan warga masyarakat, tentunya dapat diharapkan mengurangi dan akhirnya menghapus praktik lama birokrasi daerah sebagai kepanjangan pusat, yang korup dan sentralistik. Pelaksanaan otonomi daerah sekarang ini masih harus menjawab sejumlah pertanyaan besar menyangkut efektifitas dan efisiensi administratif, serta proses politik birokrasi yang penuh dengan permainan uang (money politics), sebagaimana terungkap dalam pemilihan kepala daerah tingkat kabupaten, walikota, gubernur sampai dengan perwakilan rakyat yang terjadi beberapa waktu ini. Apakah praktik korup ini akan terus berlangsung dalam pelaksanaan otonomi daerah tanpa kontrol dari kekuatan masyarakat? Kemudian, bagaimana pengaruhnya terhadap karakter sistem komunikasi di wilayah kewenangan daerah menyelenggarakan pemilihan kepala daerah. Kegiatan ini dinyatakan dalam UU Pemda No.32 Tahun 2004 Pasal 1 (20-21): Pasangan calon kepala daerah dan calon wakil kepala daerah yang selanjutnya disebut pasangan calon adalah bakal pasangan calon telah memenuhi persyaratan untuk dipilih sebagai kepala daerah dan wakil kepala daerah melalui pemilihan kepala daerah dan wakil kepala daerah di setiap provinsi dan/atau kabupaten/kota yang dilaksanakan oleh KPUD provinsi dan KPUD kabupaten/kota. Kepala daerah dan wakil daerah dipilih dalam satu pasangan calon yang dilaksanakan secara demokratis berdasarkan asas langsung, umum, bebas, rahasia, jujur, dan adil, diajukan oleh partai politik atau gabungan partai politik (UU Pemda No. 32 Tahun 2004 Pasal $56(1,2)$. Sebagai indikator dan ukuran keberhasilan dari contoh praktek korupsi pemilihan kepala-kepala daerah. 
Indikator Keberhasilan Pelaksanaan Otonomi Daerah di bidang Sosial Politik

\begin{tabular}{|l|l|}
\hline \multicolumn{1}{|c|}{ Indikator } & \multicolumn{1}{c|}{ Ukuran keberhasilan } \\
\hline - $\begin{array}{l}\text { Apakah pelaksanaan otonomi daerah } \\
\text { menjamin kebebasan bagi masyarakat } \\
\text { untuk berekspresi dan mengeluarkan } \\
\text { pendapat? }\end{array}$ & $-\begin{array}{l}\text { Tidak ada peraturan yang menyulitkan } \\
\text { penyelenggaran penelitian }\end{array}$ \\
\hline - $\begin{array}{l}\text { Apakah pelaksanaan otonomi daerah } \\
\text { menjamin kebebasan masyarakat untuk } \\
\text { membentuk organisasi? }\end{array}$ & $-\begin{array}{l}\text { Tidak ada peraturan yang menyulitkan } \\
\text { kegiatan seminar. } \\
\text { Tidak ada peraturan yang menyelidiki } \\
\text { penyelenggaraan kegiatan partai politik } \\
\text { dan organisasi kemasyarakatan. }\end{array}$ \\
\hline $\begin{array}{l}\text { Apakah pelaksanaan otonomi daerah } \\
\text { memberikan kesempatan yang luas bagi } \\
\text { masyarakat untuk mengembangkan } \\
\text { potensi yang dimilikinya? }\end{array}$ & $-\begin{array}{l}\text { Terdapat peraturan anti korupsi } \\
\text { Terdapat mekanisme yang jelas dalam } \\
\text { pola hubungan eksekutif dan legislatif. } \\
\text { Terdapat peraturan tentang peningkatan } \\
\text { kesejahteraan masyarakat. }\end{array}$ \\
\hline
\end{tabular}

\section{Sistem Lembaga Kepresidenan dan Komunikasi Infrastruktur Budaya Politik Daerah}

Di dalam struktur sistem lembaga kepresidenan tersusun dalam struktur sistem berjenjang dari mulai terbesar sampai ke unit terkecil yang ada di paling bawah. Karena itu komunikator sistem lembaga kepresidenan tersusun ke dalam tiga susun, yaitu:

a. Komunikator penyandang kebijaksanaan komunikasi

b. Konunikator penyandang program

c. Komunikator pelaksana program

Di samping ketiga susunan tersebut terdapat unit sistem yang diberi atribut unit kecil, yaitu rumah tangga otonom atau Pemda UU No. 32 Tahun 2004.

1. Komunikator penyandang kebijaksanaan komunikasi yaitu presiden dengan seluruh menteri (komunikator yang menangani masalah-masalah nasional, yang disebut multy issue matters).

2. Komunikator berikutnya komunikator pembuat program yaitu komunikator yang berada dalam lingkup departemen ialah menteri sebagai pimpinan departemen dengan seluruh pembantu menteri dengan sejumlah pejabat teras departemen (para dorektur jenderal, sekretaris jenderal dan inspektorat jenderal serta pejabat teras yang setingkat). Para komunikator ini menangani masalah khusus sesuai tugas pokok departemen yang dituangkan ke dalam program-program departemen.

Susunan bawah yaitu komunikator pelaksana program, terbagi ke dalam dua derajat program yaitu komunikator pelaksana program tingkat nasional dan komunikator pelaksana program tingkat wilayah (provinsi) dan tingkat lokal (kotamadya dan kabupaten). 
Di samping itu terdapat pula komunikator para pengelola sumber komunikasi rumah tangga unit kecil yang disebut rumah tangga otonom. Dalam kerangka totalitas sistem rumah tangga otonom merupakan bagian integral dari sub sistem suprastruktur yang berada dalam lingkup pemerintah (presiden, eksekutif).

Maka akan tampak alur komunikasi mengalir menurut struktur formal secara vertikal piramidal semakin ke atas menunjukkan kepada komunikator puncak yaitu presiden sebagai komunikator utama.

Komunikasi fungsional yang paling tinggi tingkat frekuensinya antara (dua sub sistem suprastruktur yaitu eksekutif (Presiden) dengan DPR, terutama dalam membentuk landasan normatif yang menjadi dasar pijak para komunikator suprasutruktur) sekaligus sikap perilaku masyarakat sebagai komunikan. Landasan normatif ini dalam bentuk perundangan.

Jalinan komunikasi fungsional mengandung, makna terjadinya proses komunikasi antara fungsi dominan yang bersifat menyamping atau komunikasi horisontal. Dalam istilah manajemen disebut koordinasi. Terjadinya proses komunikasi horisontal berlangsung dalam ikatan-ikatan normatif pula (berdasar Undang-Undang Dasar).

Dalam sub sistem lembaga kepresidenan tampak dua alur komunikasi, yaitu alur ke samping sebagai jalinan komunikasi horisontal dan alur ke bawah sebagai alur vertikal.

Jalinan komunikasi fungsional berlangsung pula dalam rumah tangga sub unit sistem suprastruktur yang disebut unit rumah tangga otonom, yaitu antara kepala daerah (gubernut untuk tingkat I, bupati atau walikotamadya untuk tingkat II dengan DPRD (Tingkat I atau tingkat II). Dalam alur vertikal jangan diartikan sebagai komunikasi satu arah, tapi harus diartikan komunikasi dalam arus atas ke bawah dan arus bawah ke atas. Dalam struktur seperti berikut :

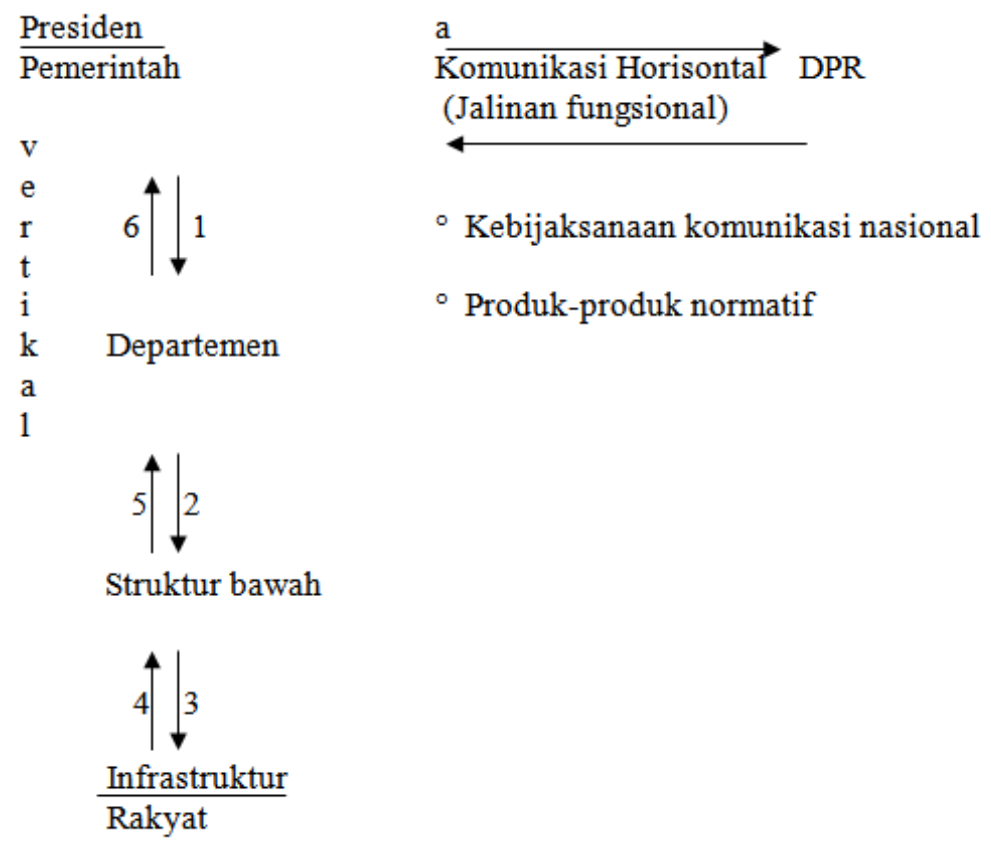


Jalinan komunikasi antara suprastruktur komunikasi dengan infrastruktur komunikasi menunjukkan bahwa proses sistem berlangsung seimbang. Kelenturan kehidupan infrastruktur komunikasi merupakan karakteristik sistem komunikasi Indonesia sebagai faktor pembeda terhadap sistem komunikasi lainnya.

Infrastruktur komunikasi terdiri dari para komunikator politik, komunikator profesional dan para aktifis. Para komunikator ini selalu menjalin komunikasi dengan komunikator suprastruktur. Karena itu infrastruktur komunikasi merupakan lembaga input bagi suprastruktur komunikasi.

Arus input memasuki wilayah pranata kekuasaan lebih luas, yaitu wilayah pranata pemerintahan. Lembaga perwakilan dan lembaga tertinggi negara. Input yang memasuki wilayah lembaga-lembaga otoritas sebagai bahan untuk menentukan kebijaksanaan komunikasi nasional diangkat dari wilayah komunikan (wilayah infrastruktur).

Infrastruktur komunikasi merupakan faktor dominan yang dapat mempengaruhi kelangsungan dan kelestarian sistem. Dalam kaitannya dengan sistem nilai luar, infrastruktur komunikasi merupakan benteng penyangga terhadap terpaan luar "yang mengemas nilai-nilai negatif."

Akar sistem komunikasi nasional berada dalam wilayah tradisi, adat dan budaya daerah yang secara keseluruhan berada pada infrastruktur komunikasi. Maka akan tampak kesuburan infrastruktur komunikasi, sehingga infrastruktur komunikasi merupakan faktor dominan yang dapat berpengaruh terhadap kelangsungan dan kelestarian sistem. Selain itu infrastruktur sebagai akar komunikasi nasional yang merupakan pula identitas pembeda terhadap sistem-sistem komunikasi nasional lainnya.

Disamping kelompok-kelompok yang telah diuraikan di atas, satu hal lagi yang perlu dipahami yaitu unit sub sistem infrastruktur yang berada dalam wilayah kultural (culture area) atau menurut istilah hukum adat sebagai wilayah adat dan menurut istilah komunikasi sebagai wilayah komunikasi tradisional atau budaya politik tradisional dalam konteks sosial politik. Hal ini penting karena akar-akar sistem muncul dari wilayah tradisi, adat atau budaya daerah. Secara normatif sub sistem ini diayomi oleh pasal 32 Undang-Undang Dasar 1945, di dalam penjelasan pasal 32 tersebut ditetapkan bahwa:

Kebudayaan bangsa ialah kebudayaan yang timbul sebagai buah usaha budi rakyat Indonesia seluruhnya. Kebudayaan lama dan asli yang terdapat sebagai puncak-puncak kebudayaan di daerah-daerah seluruh Indonesia, terhitung sebagai kebudayaan bangsa. Usaha kebudayaan harus menuju ke arah kemajuan adab, budaya dan persatuan dengan tidak menolak 
bahan-bahan baru dari kebudayaan asing yang dapat mengembangkan atau memperkaya kebudayaan bangsa sendiri, serta mempertinggi derajat kemanusiaan bangsa Indonesia.

Penjelasan Undang-Undang Dasar 1945 tersebut menunjukkan bahwa demikian kayanya bangsa Indonesia akan budaya daerah, sekaligus termasuk di dalamnya kekayaan akan lambanglambang komunikasi yang menyatu dengan budaya daerah tersebut.

Fungsi yang melekat pada komunikasi adalah bagaimana mengintegrasikan etnis budaya dan kelompok-kelompok infrastruktur ke dalam sistem nilai yang dijunjung tinggi bersama sehingga sistem terus berproses sampai mencapai tujuan sistem. Dalam konteks sosial politik budaya politik pemerintah selayaknya menghargai dan mempertahankan dan menyatukan budaya politik tradisional secara integratif dalam integrasi politik pemerintahan daerah

\section{Pergeseran Peran Desentralisasi dan Administrasi}

Peran berkaitan dengan kekuasaan dan kedudukan maupun interaksi atau saling keterkaitan antar peran sebagaimana diharapkan oleh peran-peran tersebut bersumber pada konsep diri dan dunianya. Peran identitas daerah dalam pelaksanaan otonomi daerah terkait dengan konsep diri dan kesukuan identitas daerah sebagai manifestasi dari nilai dan budaya daerah.

Inilah peran sosial politik dalam budaya politik tradisional sebagaimana paparan sebelumnya. Jadi peran dalam konteks pelaksanaan otonomi daerah adalah keterbukaan global dan multiperan dalam jaringan komunikasi antar daerah yaitu jaringan komunikasi nasional dan jaringan komunikasi internasional.

Pergeseran peran dengan ciri-cirinya dari birokrasi sentralistik atau peran SKI "Lama" mengikuti pola "Roda" dalam stuktur komunikasi nasional dan pola "Segenap Saluran" dengan cirinya adalah sebagai SKI "Baru" yang lebih jelas dalam matrik diagram paparan sebelumnya (Rumondor, 2001)

\section{Permasalahan Pokok}

Terdapat empat butir latar belakang perubahan dan temuan-temuannya serta dua contoh kasus permasalahannya. Perubahan tatanan pemerintahan otonomi daerah dengan kewenangannya; propinsi pemerintahan daerah dalam kepemimpinan para bupati, walikota dan camat -- sepertinya belum begitu disadari dan dipahami benar oleh para pejabat publik dalam meningkatkan peran sistem komunikasi nasional baru menjawab tantangan politik pemerintahan daerah. Bahwa tidak mungkin perubahan tatanan pemerintahan yang diembannya dapat 
diselenggarakan tanpa pemahaman terhadap perubahan komunikasi dalam tindakan-tindakan komunikasinya. Sebab tanpa komunikasi proses terselenggaranya pemerintah yang demokratis, tidak akan dapat berlangsung. Di sisi lain, tanpa disadari gusuran demokrasi sentralistik dan komunikasi sosial akan dapat menimbulkan krisis bahkan konflik berkepanjangan hanya karena benturan budaya politik pemerintah dengan budaya politik tradisional masyarakat di daerah. Inilah masalah integrasi politik negara yang dihadapi dalam sistem NKRI. Pergeseran peran kepemimpinan adalah sebagai peningkatan kredibilitas kepemimpinan membangun terus komunikasi sosial dan sistem informasi integratif dalam jaringan pemerintahan daerah. Ini berarti penting dipelihara dan dipertahankan keseimbangan yang saling tergantung dan saling berpengaruh secara timbal balik. Dicegah terjadinya kemampetan komunikasi antara suasana kehidupan komunikasi dalam pemerintahan (suprastruktur komunikasi) dan suasana kehidupan komunikasi di dalam masyarakat (infrastruktur komunikasi). Inilah sistem komunikasi nasional "Baru" mengatasi masalah integrasi politik pemerintah daerah di Republik Indonesia yang kita cintai.

\section{Contoh Kasus I}

\section{Konflik Penduduk Amungme dengan PT Freeport Indonesia dan Pemda di Irian Jaya}

Pada 1967 PT Freeport Indonesia (FI) adalah investor asing yang menanamkan modal di Indonesia sejak pemerintahan Orde Baru. Pada saat itu jumlah penduduk Amungme di desa Waa hanya 500 jiwa. Dengan adanya kegiatan PT. FI keluarga-keluarga Amungme dari Tsinga, Aroanop dan desa di sekitarnya mendatangi desa Waa. Tidak hanya itu, suku-suku pegunungan sekitarnya seperti Dani, Ekari, Moni dan Damal berdatangan ke desa ini untuk mencari pekerjaan atau sisa-sisa barang dan makanan yang ada.

Konflik pertama muncul pada 1967 ketika sejumlah orang Amungme berkeberatan terhadap pengeboran di Ertzbeg yang dilakukan oleh tim Forbes Willson dari PT. FI. Alasan mereka adalah karena tempat itu keramat. Pihak PT. FI segera menjemput pemimpin Amungme yang disegani yakni Kelangin Tenbak dengan helikopter ke Waa. Kelangin menjelaskan kepada penduduk bahwa mereka hanya meneliti batu-batuan, tetapi ia tidak mengatakan bahwa apabila hasil penelitian membuktikan batu-batuan tersebut berharga maka gunung itu akan dibongkar. Setelah pengeboran selesai dan Tim Peneliti meninggalkan tempat penelitian, penduduk setempat merusak semua peralatan dan mencuri barang-barang.

Protes dan gangguan orang Amungme terhadap PT. FI semakin kuat pada 1973. Menyadari hal ini PT. FI dan pemerintah segera merekayasa persetujuan yang dikenal dengan 
"January Agreement 1974". Hingga hari ini masyarakat menganggap perjanjian ini dibuat dibawah tekanan dan intimidasi. Selain itu pimpinan lokal waktu itu buta huruf dan tidak mengerti implikasi dari perjanjian. Bahkan isi perjanjian tidak ditepati sepenuhnya oleh pihak PT. FI. Pada gejolak sosial 1977 Organisasi Papua Merdeka (OPM) melancarkan aksinya. Angkatan Bersenjata Republik Indonesia (ABRI) menghancurkan fasilitas umum yang sudah dibangun oleh PT. FI sebagai bagian dari usaha memerangi OPM. Setelah masalah OPM mereda, pemerintah tetap melarang PT. FI untuk membangun kembali fasilitas tersebut.

Pasca Gejolak Sosial 1977 keadaan relatif tenang di Mimika Timur. Namun ketergantungan hubungan antara Masyarakat Amungme dengan PT. FI masih terasa di bawah permukaan. Tidak ada satu kerusuhan pun yang yang mencuat ke permukaan. Pada 1983 kembali ketegangan mencuat ketika tersebar isu bahwa kota Tembagapura akan dihancurkan oleh OPM dengan bantuan orang-orang Amungme yang sudah bekerja pada PT. FI. Penangkapan terhadap pegawai Amungme dilakukan sepihak, yang ketakutan melarikan diri ke hutan. (Analisis CSIS, Tahun XXVI No.3, Mei-Juni 1997)

\section{Pemerintah Pusat dan Daerah}

Hingga empat tahun yang lalu, PT. FI biasa melakukan apa saja tanpa konsultasi dengan pemerintah kecamatan. Beberapa tahun terakhir ini PT. FI memang sering beronsultasi sehubungan dengan rencana kegiatan mereka. Namun demikian PT. FI di Timika tetap dominan dalam menentukan pengembangan wilayah Mimika Timur. Pemerintah lokal terkendala oleh masalah anggaran, waktu, keterlambatan pengambilan keputusan dan sumber daya manusia. Selain itu banyak hal di Timika -yang menjadi bagian Kabupaten Fak-fak- harus diputuskan oleh bupati. Di kalangan masyarakat muncul persepsi bahwa pemerintah setempat dikendalikan oleh dan bergantung pada fasilitas PT. FI. Tidak hanya itu, kunjungan dari pejabat propinsi atau pusat selalu dilakukan langsung dengan PT FI. Pertemuan formal pun sering terjadi di Tembagapura dengan fasilitas PT. FI, bukan di Kabupaten Fak-fak.

Kredibilitas pemerintah setempat di mata masyarakat luas sedang mengalami krisis. Masalah-masalah dan tuntutan yang muncul dari masyarakat hampir tidak pernah disampaikan ke camat. Mereka cenderung menyampaikan tuntutan dan masalah mereka secara langsung ke PT. FI karena mereka beranggapan pemerintah kecamatan kurang tanggap dan kemampuan sumber dayanya sangat terbatas sedangkan PT. FI bisa menyelesaikan dan memenuhi berbagai tuntutan secara cepat. Selain itu dalam masyarakat terdapat persepsi bahwa kecamatan lebih melayani kepentingan PT. FI daripada masyarakat. 
Pada sisi lain terlihat pula dominasi pemerintah pusat di Irian Jaya. PT. FI dalam banyak hal lebih banyak berkonsultasi dengan pemerintah pusat di Jakarta. Diakui oleh banyak pihak bahwa Kontrak Karya PT. FI 1967 dan 1991 sama sekali tidak melibatkan Pemda Tk I, Tk II, apalagi kecamatan. Bahkan sejumlah anggota DPRD Tk I mengaku tidak mengetahui isi Kontrak Karya itu. Berdasarkan hal ini maka dapat dipahami mengapa dalam krisis HAM 1995 justru Pemda Tk I yang mengkritik PT. FI dalam konferensi Pers. Demikian pula di Timika pejabat Pemda setempat dan Perwira Kodim dan Polres mengkritik PT. FI dalam perencanaan dan pembangunan kota Kuala Kencana. Bahkan salah seorang dari mereka mengatakan, "Kuala Kencana suatu saat akan menjadi Kuala Bencana”.

\section{Contoh Kasus II}

\section{Budaya Politik "Lain-lain” Versus Budaya Politik Negara}

Persepsi, aspirasi, cara pandang dan reaksi yang terwujud dalam perilaku politik masyarakat "lain-lain" di Timika dalam kaitannya dengan konflik yang mereka alami dengan PT. FI, pemerintah dan ABRI, ditentukan oleh budaya politik tradisional mereka. Pada contoh kasus II ini dipaparkan anatomi konflik budaya politik, terutama sistem kepercayaan, pandangan dunia, mitos dan ideologi yang menjadi basis interaksi sosial dan politik serta kepemimpinan. Selain itu pengalaman historis hubungan politik dan upaya pembangunan yang dilakukan oleh PT. FI dan pemerintah.

Pada masyarakat pegunungan di Irian Jaya telah berkembang ideologi yang meyakini tiga jenis relasi: manusia-alam-supra alam. Seluruh kehidupan, kesejahteraan atau kehancuran, ditentukan oleh keberhasilan menjaga hubungan timbal-balik manusia supra alam. Alam dan benda-benda sakral hadir sebagai representasi dunia supra alam. Pada tempat tertentu seperti gunung, lembah, tanah ladang dan rawa terdapat tempat-tempat yang dinilai sangat sakral dan oleh sebab itu dihormati.

Dalam sistem kepercayaan Amungme tanah tempat manusia berpijak disimbolkan sebagai ibu dan Ertzberg adalah bagian kepala (ninggok). Tempat ini dipercaya sebagai rumah bagi roh-roh nenek moyang mereka. Bila tempat ini sampai dirusak maka relasi manusia Amungme dengan supra alam mengalami guncangan. Kematian, bencana alam, dan kekacauan sosial dikhawatirkan terjadi. Ketakutan akan hukuman dari roh-roh nenek moyang di satu pihak dan kemarahan karena tempat sakral tersebut tidak dihormati oleh para orang asing di lain pihak, membuat orang Amungme menunjukkan reaksi yang sangat keras. 
Kemarahan dan ketakutan meningkat seiring dengan peningkatan kegiatan PT. FI yang membutuhkan lahan yang semakin luas. Selama hampir 30 tahun -sejak 1967- mereka menyaksikan pembangunan jalan yang menyusuri bukit, peledakan bukit, dan pembangunan kota Tembagapura yang kemudian diresmikan oleh Presiden Soeharto pada 1973. Lingkungan alam mereka mendadak mengalami perubahan. Orang-orang asing itu mengeksploitasi tanah dan gunung mereka tanpa ada rasa takut, tanpa hormat, tanpa penghargaan pada keyakinan lokal tentang nilai sakral.

Dalam konflik pertanahan terlihat bahwa perubahan yang berkaitan dengan tanah dipandang oleh masyarakat "lain-lain" sebagai persoalan ideologis. Eksploitasi tanah dan perlakuan terhadap tanah oleh PT.FI dihadapkan langsung dengan pandangan kosmologis Amungme tentang dunia dan keyakinan religius mereka. Ideologi tentang tanah ini sebenarnya diketahui pihak PT.FI dan Pemerintah, namun pertimbangan lokal tersebut tidak pernah diperhitungkan. (Analisis CSIS, Tahun XXVI No.3, Mei-Juni 1997)

\section{Penutup}

Dari dua contoh kasus ini bisa disimpulkan bahwa konflik di Timika bersumber pada kesenjangan budaya politik. Kesenjangan ini kemudian diperburuk oleh kenyataan historis hubungan antar masyarakat "lain-lain", pemerintah, ABRI dan PT. FI. Selama 30 tahun, kesenjangan budaya politik bukannya dimediasi dengan dialog budaya tetapi justru diperlebar dengan berbagai praktek politik dari pemerintah, pemda, ABRI, dan PT. FI. Akibatnya di kalangan masyarakat "lain-lain" sudah tertanam sikap permusuhan yang sangat kuat pada pihak luar. Keengganan untuk dialog dan kecenderungan dominasi yang kuat dari pihak luar akhirnya melahirkan perlawanan masyarakat "lain-lain" dengan cara kekerasan.

Untuk memperbaiki hubungan sosial dan membantu masyarakat lokal memberdayakan diri mereka sendiri harus dimulai dengan pemahaman yang komprehensif tentang peran sistem komunikasi nasional baru dalam kepemimpinan aparat pemda; bupati, walikota dan camat di kabupaten Fak-Fak terutama mengatasi gusuran (birokrasi sentralistik) dan memahami pula realita pergeseran perannya ke birokrasi desentralisasi. Dalam konteks sosial politik memelihara dan mempertahankan kebudayaan Amungme dan Komoro melalui penelitian ilmiah jangka panjang. Pemahaman ini selanjutnya dapat dijadikan basis perencanaan program-program pemberdayaan masyarakat. Karena hubungan masyarakat, pemerintah dan PT. FI yang masih buruk, sebaiknya dilibatkan Lembaga Swadaya Masyarakat (LSM) untuk berperan sebagai mediator. Perencanaan, pelaksanaan hingga evaluasi harus dikerjakan dengan partisipasi penuh dari masyarakat "lain-lain". 
Lembaga adat lokal yang bisa memunculkan peran pemimpin dan mewakili kepentingan masyarakat "lain-lain" perlu segera dibentuk dengan bantuan LSM luar. Lembaga ini akan menjadi wahana belajar bersama bagi pemimpin lokal dengan advokasi LSM. Lembaga ini juga berkaitan dengan persiapan masyarakat "lain-lain" untuk melakukan negosiasi baru dengan PT. FI dan pemerintah dalam rangka penyelesaian tanah dan isu-isu lainnya yang selama ini belum terpecahkan.

Gagasan pemberdayaan itu sebagaimana digariskan dalam pertimbangan normatif UU No.32 Tahun 2004 tentang pemerintahan daerah mengatasi masalah integrasi politik desentralisasi serta meningkatkan peran kredibilitas kepemimpinan dalam komunikasi sosial dengan budaya politik tradisional yang dikaji bersama serta sistem komunikasi politik otonomi daerah oleh pemda. 


\section{Daftar Pustaka}

Boulding, Kenneth E. 1989. Three Faces of Power, Newbury Park, California: Sage Publications.

Care,Y.W. 1975. A Cultural Approach to Communication.

Doughty, Philip. 1990. Human Resources Development and Management-IUC-IDIA Seminar Syracuse Universitas Trisakti. Jakarta.

Goldhaber. Gerald M. 1986. Organizational Communication. Fourth Edition. Dubuque, IA: Wm. C. Brown Publishers.

Greenbaum, Howard H. and Falcione, Raymond L. 1980. Organizational Communication, California: Sage Publications.

Jusman Iskandar C.S, 2000. "Pemberdayaan Masyarakat" Sekolah Tinggi Ilmu Administrasi Lembaga Administrasi Negara RI. Bandung

Katz, D. and Kahn, R.L. 1978. The Social Psychology of Organizations, New York: John Wiley \& Sons.

Kreps, Garry L. 1986. Organizational Communication, Foundation for Human Resources Development. New Jersey: Englewood Cliffs.

Rumondor Alex, 2011 "Tantangan Kepemimpinan Manajemen Organisasi Perguruan Tinggi Prediktor Efisiesi Manajemen Sistem Pendidikan Nasional"

, 2007. Manajemen Hubungan Masyarakat Modul FISIPOL UKI Tahun 2007SOP Update Package Learning Pembuatan Modul

, 2007. Komunikasi Antar Budaya Modul FISIPOL UKI, Tahun 2007-SDP Update Package Learning Pembuatan Modul

, 2001. Communication Climate Predictor of Overall Job Satisfication among the Sales Representatives: A Study of Organizational Communication, Human Resource Development and Management among the Sales Representatives in the Company Organization in Jakarta. Disertasi

Nurdin. 2005. Sistem Komunikasi Indonesia. Jakarta : PT. Raja Gratindo Persada.

Burgoon, Michael. 1982. Communication Yearbook 5, New Jersey: The International Commmunication Association.

Sembiring, Sentosa. 2009. Pemerintah Daerah, "Himpunan Peraturan Perundang-Undangan RI"

Soemirat, Soleh, Elvinaus Ardianto, Jessy Ratna. Seminar 2000 Komunikasi OrganisasionalMateri Pokok SKOM 4329 (3 SKS Modul 1-4) Universitas Terbuka 
122 Rumondor, Tantangan Peran Birokrasi Sentralistik, Integrasi Politik Pemerintahan Daerah, Prediktor ...

Sumarso APCS. 2000. Modul UT "Sistem Komunikasi Indonesia"

Centre for Strategic and International Studies, Analisis CSIS, Tahun XXVI No.3 Mei-Juni 1997 "Liberalisasi, Migrasi dan Pemberdayaan Masyarakat"

Pokok-Pokok Pikiran UKI, 1998 “Dalam Rangka Reformasi Menyeluruh”, Lembaga Penerbitan UKI 1998.

\section{Dokumentasi}

Anggota IKAPI. 2009. UUD 1945 Dan Perubahannya serta Struktur Ketatanegaraan. Jakarta: Indonesia Tera.

Himpunan Peraturan dan Perundang-Undangan - UU No. 33 Tahun 2004 Tentang Pemerintahan Daerah.

UU RI No. 32 dan 33 Tahun 2004 tentang OTODA 